\title{
Can Monetary union Enhance Banking Competition?: A Multicase Study
}

\author{
Natalia Utrero-González \\ Universitat Autònoma de Barcelona \\ Francisco J. Callado-Muñoz \\ Universitat de Girona
}

\begin{abstract}
The deregulation of financial services in the European Union and the development of information technology have fostered recent changes in the European banking industry. This process, that has affected market competition, has been accelerated by the establishment of the Economic and Monetary Union (EMU). This paper makes a comparative analysis of the market conditions for banking sectors in Spain and France (EMU participation countries) and UK and Denmark (not participating in EMU) in order to assess the effects of the adoption of the Single currency in banking market conditions. This comparison is made distinguishing between commercial banks and non-profit financial institutions.
\end{abstract}

- JEL Classification: G21, L10

- Keywords: Banking Competition, Market structure, Economic integration, EMU

\section{Introduction}

The European banking industry is currently facing the effects of the integration of the different national financial markets. This integration results from the

\footnotetext{
*Corresponding address: Natalia Utrero-González, UAB, departament d'Economia de l'Eupiesa, Campus de Bellaterra 08193-Cerdanyola del Vallès (Baseelne), E-mail: natalia.utrero@uab.es Francisco J. Callado-Muñoz, Universitat de Girona, departament d'Economia. Campus de Montilivi 17071 Girona E-mail: franciscojose.callado@udg.es

(C2007-Center for International Economics, Sejong Institution, All Rights Reserved.
} 
elimination of the controls on capital movements agreed in 1989; the come into effect of the Second Banking Directive in 1993 that allows banks from European Union (EU) countries to branch freely into other EU countries and mainly the introduction of the single currency (EMU) in 1999. The prospect of the European single banking market and the concern for competitive pressure from foreign rivals have undoubtedly influenced the competition policy of domestic banks (Coccorese, 2004). This enhanced competition has forced banks to look for a bigger size as well as better managerial capability in order to improve their overall efficiency. Accordingly, during the last decade the number of concentration processes has increased sharply in EU countries. This increasing competition has taken place together with the maintenance of a kind of financial institutions that have ownership structures different from the usual shareholder-owned firms. In the case of Spain, Denmark and France, savings banks that compete for deposits and loan with the usual commercial banks, are financial institutions with no formal owners and there is no market for their corporate control. French mutual banks compete with commercial banks and are the second type of institutions in percentage of total assets. In the case of UK, building societies were in the beginning true mutuals which were customer-owned and could only engage in housing finance. After the 1997 Act, Building Societies can perform a wide range of commercial activities. However, it could be said that the benefits of the society's wider activities were still intended to accrue to the members (in the form of cheaper loans, in the case of borrowers, or higher savings rates in the case of investors) acting in a manner akin to entities without owners, (Cook et al., 2001). Therefore, taking into account these distinctive characteristics, savings banks, mutual banks and building societies can be considered as non-profit organizations in the sense of Hansmann (1996).

The availability of data for the first years of the EMU gives us the opportunity to analyse its impact on the European banking structure. Two relevant questions arise. First, whether banking structure might be affected differently in Euro countries and those countries not adopting the Single currency. Second, whether institutions with distinct ownership structures will respond differently to competitive pressures. This paper considers these questions analysing a sample of financial institutions, for Spain, France, Denmark and UK, during the period 1996-2002.

To evaluate the degree of competition in these banking industries, we apply a methodology first proposed by Rosse and Panzar, the so called "H statistic", which is the sum of elasticities of revenue to the components of expenditure. Following 
De Bandt and Davis (2000), competitive conditions are estimated in terms of total income. As a difference with previous works, the competitive conditions are estimated taking into account the type of ownership structure of the banking institution. This is considered highly relevant, first, because the national deregulatory process of both types of institutions has important differences and second, because previous empirical evidence supports the view that non-for profit and investor-owned companies provide distinct solutions to the problems which are inherent in corporate governance (Cook et al., 2001). Therefore, non-for-profit and investor-owned institutions can not be considered as perfectly substitutes.

The paper is structured as follows. In section 2 the main changes in the banking markets in UK, Denmark, France and Spain are summarized and the expected impact of Euro is briefly examined. Section 3, reviews previous literature and section 4 presents the methodology of analysis and the data used. Section 5 discusses the main results and finally section 6 draws some conclusions.

\section{Banking Structure in UK, France, Denmark and Spain and the EMU}

Banking markets in the OECD countries have been subject to an enormous degree of structural change since the early 1980s. This structural change has been associated with increasing competition, both within and across sectors, with the impact of new technologies, which facilitates the competition from new entrants and more recently through regulation changes, especially in the EU countries. For example, the come into effect of the Second Banking Directive opens up a process of competitive deregulation leading to the adoption by all EU member states of the universal banking model. ${ }^{1}$ These changes cause banks to foster their focus on noninterest income.

The UK banking industry has not been strange to this trend. The combined impact of new technology and new entrants has resulted in an increasing competitive environment. Despite this evolution, the markets to supply banking services to small and medium sized businesses (SMEs) are much less competitive than those which face individual customers since the problems associated to

\footnotetext{
The banking model suggested by the Second Banking Directive is the Universal Banking Model, which allows banks to carry on traditional activities such as deposit acceptance and the granting of loans in addition to investment activities such as money brokering, portfolio management and securities underwriting.
} 
switching, information and representation are more significant there. Furthermore, the markets to supply these services are extremely concentrated and barriers to entry are high, (Cruickshank, 2000).

A second accelerator of changes has been the deregulation of the Building Societies sector. Building societies are member-based institutions. Therefore, those opening an investment or mortgage account become a member of the society and have the right to receive information about the way the society is run and to attend general meetings. The key advantage of this kind of mutual institution over its plc competitors is that they do not need to pay dividends to equity shareholders. This distinct ownership structure coupled with discrete regulation have enabled building societies to become a distinct financial service in the UK, mainly offering lower cost mortgages ${ }^{2}$, (Ashton, 2000). Cook et al. (2001), claim that they can be considered non profit companies in the sense of Hansmann (1996), that is, entities with no formal owners. In fact, building societies are the most important non-forprofit institutions in UK. The Building Societies Act 1986 opens the way for competition with commercial banks, allowing building societies to offer a wider product portfolio ${ }^{3}$. The Act of 1997 allows a building society to choose its own subsidiary purposes by reference to its memorandum of association. The implication of this change is that building societies could now engage in a wider range of commercial activities, (Cook et al. 2001). Outside individual customers, ${ }^{4}$ building societies are currently active in lending to housing associations, have commercial loan portfolios and raise 20 per cent of their funds from the wholesale money markets rather than individual investors. ${ }^{5}$ This evolution is extremely important such that, not only building societies have tended to dominate certain segments of the financial services market, but they also enjoy a superior public image than their plc counterparts ${ }^{6}$ and compare very favourable in terms of performance measures such as relative profitability and cost/income ratios, (Drake

\footnotetext{
${ }^{2}$ Through this services, Building societies serve their customers because that is their ultimate goal

${ }^{3}$ At the same time, it introduces a procedure for 'demutualization', that is to say, the conversion of building societies into investor-owned commercial companies.

${ }^{4}$ Nowadays societies account for $20 \%$ of residential mortgages and $18 \%$ of personal deposits.

${ }^{5}$ Building Societies Association (2000).

${ }^{6} \mathrm{~A} \mathrm{BBC}$ survey in 1998 found that $44 \%$ of respondents would trust a building society to get a mortgage while $23 \%$ would trust a commercial bank, Building Societies Association (2000).
} 
and Simper, 2003). The concentration of the UK banking industry, as in the European Union, has been important and fostered by a process of mergers that was initiated mainly in 1990 (ECB (1999) and Dermine (2002)).

The Danish banking sector is a regulated industry where three main institutions, commercial banks, saving banks and credit cooperatives compete under equal conditions in the loan, deposit and financial service market. The deregulation that eliminated the differences among them took place in 1974 by the enactment of the Commercial and Savings banks law. This law was reformulated in 1996 to be adapted to the second European banking directive. Commercial banks are the most important financial institution in the Danish banking system. They account for more than 90 per cent of assets followed by savings banks with 6-7 per cent. The importance of credit cooperatives is very limited.

With respect to the concentration, this is very important on the side of commercial banks and it has been fostered by a process of mergers that was initiated in 1990. On the side of savings banks, institutions are much smaller. In fact, savings banks have a clear regional and local character, as in the case of Spain, and some of them have only one branch in their origin market. From 1988, savings banks were allowed to convert themselves into investor-owned commercial companies as in the case of Building Societies in the UK. The three bigger savings banks have changed their nature and others have shown their willingness to merger with commercial banks.

In the case of France, the banking sector is also a regulated industry but the number and kinds of institutions are a bit more complex. From the enactment of the 84-86 law in 1984, the universal banking model was established for all financial institutions of the territory. However, this universal banking model does not mean that there are not differences among institutions. Under this law, four major classes of financial institutions can be distinguished: commercial banks, mutual and cooperative banks, savings banks and municipal loan savings banks compete under equal conditions in the loan, deposit and financial service market. Besides this grouping, within each category there are further classifications attending to particular differences depending on their objectives, nature etc. They account for more than $80 \%$ of assets in the French market. The rest corresponds to other institutions that have their activities limited by the licence they receive, mainly related to credit services to particular sectors.

Again, as in the case of the Danish banking system, commercial banks are the most important financial institution in France and account for around 60 per cent of 
assets. Mutual banks follow with a 17 per cent of assets but a 22 per cent of credits and deposits. Within the mutual bank category, there are four types of institutions: mutual agriculture credit institutions, people banks, mutual credit savings banks and cooperative credit institutions. Each type of institution is organised around a national association. By regulatory provisions, they are restricted to geographic areas or certain types of clients. However, the amount of credits and deposits held reflects the clear vocation to retail banking of these institutions. French savings banks retain 6 per cent of assets but 8.8 per cent of deposits stressing their importance in channelling savings into the financial system. As savings banks have no formal shareholders, they must either retain their earnings or invest them in social and cultural programs. Therefore, they are non-profit organizations in the sense of Hansmann (1996). The importance of municipal loan savings banks is much more limited.

With respect to the concentration, the French banking system, in general, is very concentrated and this concentration has been growing in the last years. This increase in concentration has affected also savings banks. Given their special characteristics, in 1991 it was enacted a law to promote mergers among them. The number of savings banks went from 186 in 1991 to only 35 in 1996.

Related to Spain, the banking sector is a regulated industry where, as in the Danish case, three main institutions, commercial banks, saving banks and credit cooperatives compete under equal conditions in the loan, deposit and financial service market. As their French counterparts, Spanish savings banks are non-profit organizations in the sense of Hansmann (1996) with a social contribution. They concentrate on retail banking, providing checking, savings and loan services to individuals. Commercial and savings banks account for the 95 per cent of the loan and deposit markets (Crespi et al., 2003). Spanish savings banks were chartered to a particular geographical area and it was not until 1989 that are allowed to expand beyond their traditional geographic markets. This deregulation permitted nationwide expansion. In 1999 Spanish savings banks accounted for the highest proportion of total bank deposits held by saving banks in EU, (Staikouras and Wood, 2000).

During the last decade, as it is the case at a European level the process of concentration in the Spanish market has been very intense (Dermine, 2002). The increased competition in the sector and the lower profit margins due to the persistent decline in the interbank interest rate- as a result of the nominal convergence of the Spanish economy towards the EU- have fostered many mergers 
among banks. Savings banks have also been affected by this merge wave. There were 362 credit institutions in 1997 compared with 696 at the beginning of the nineties (ECB, 1999). Fifty-one (14 per cent) of these are saving banks. However, savings banks have 46.9 per cent of the deposit market and 52 per cent of the mortgage market in June 2003. Furthermore, Spanish savings banks enjoy as the British mutual institutions a superior public image and they are perceived differently by consumers. ${ }^{7}$ In all four countries, competition among these non for profit banking institutions and commercial banks is getting tighter. In such a context, the introduction of the EMU was expected to have an additional effect on interbank competition due to the cross border banking as different papers have highlighted.

The availability of post-EMU data allows us to assess the extent to which the adoption of the Single currency has affected the degree of competition in the banking sectors of four members of the EU-Spain, France, Denmark and UK-being the latter two outside of the Single currency as well as to assess predictions and verify results for earlier periods. Furthermore, we can test whether the adoption of the single currency affects differently plc and non-for-profit institutions. The election of these countries responds to an additional research interest, can the competitiveness of the banking sectors of the countries outside the European currency be negatively affected by this decision? or as a British officer claimed recently, the UK banking sector does not need the EMU to be competitive. This analysis is realised controlling the distinctive features just commented to account for the single currency impact and avoid spurious correlations. The results will extend the recent literature on the EMU expected changes and provide a background to assess the UK, Denmark and Sweden decision to continue out of the EMU.

\section{Literature Review}

The economic literature offers different methods to assess market competition. ${ }^{8}$ The theory of contestable markets has drawn, however, attention to the fact that there are several sets of conditions that can yield competitive outcomes even in concentrated systems. On the other hand collusive actions can also be sustained

\footnotetext{
${ }^{7}$ Spanish Federation of Savings Banks, CECA (2004).

${ }^{8}$ Angelini and Cetorelli (2000) present a complete review of the main contributions.
} 
even in the presence of many firms.

Bresnahan (1982) and Lau (1982) propose a technique based on general market equilibrium. The basic idea is that profit-maximizing firms in equilibrium will choose prices and quantities such that marginal costs equal their (perceived) marginal revenue. The empirical implementation of the model requires the estimation of market demand and supply curves simultaneously. This method has been successfully implemented in the banking context by Shaffer $(1989,1993)$, Coccorese (1998b) and Bikker and Haaf (2002).

Rosse and Panzar (1977) and Panzar and Rosse (1982) and (1987) develop a method for the identification of market power and consists in estimating the so called $\mathrm{H}$ statistic. Panzar and Rosse show that the $\mathrm{H}$ statistic can be used to infer the competitive structure of the industry in which the firm operates. This test derives from the New Industrial Organisation literature. It is based on reduced form of revenue functions and uses firm-level data. Market power is measured by the extent to which changes in factor prices are reflected in revenues. More specifically, the $\mathrm{H}$ statistic measures the percentage change in a firm's equilibrium revenues caused by one percent change in all of the firm's input prices.

With perfect competition and when firms operate at their long run equilibrium, a proportional increase in factor prices induces a shift in gross revenues in the same proportion. That is, output does not change in volume terms, while the output price rises to the same extent as the input price (i.e. demand is perfectly elastic). Then the $\mathrm{H}$ statistic is equal to one ${ }^{9}$. Under monopolistic competition or where potential entry leads to contestable market equilibrium, revenues will increase in a minor proportion, as demand is inelastic (Tirole, 1988). Therefore, the H statistic will lie between zero and unity. In the case of monopoly, revenues will respond in the opposite direction to a change in input prices as an increase in marginal costs will reduce output and revenue, then $\mathrm{H}$ is less than zero (Panzar and Rosse, 1987). From an econometric point of view, the rejection of the $\mathrm{H} 0$ hypothesis $(\mathrm{H}<0)$ rules out the monopoly model; the rejection of the hypothesis $(\mathrm{H}>1)$ excludes all the above three models; and the rejection of both the $\mathrm{H} 0$ and $\mathrm{H}=1$ hypothesis (but not the $\mathrm{H} 1$ hypothesis) implies that only the monopolistic competition model is consistent with the data (Panzar and Rosse, 1987 p. 453). Furthermore, Panzar and Rosse (1987) stress that is not only the sign of the $\mathrm{H}$ index what is important, but also its magnitude. Hence, the more negative the $\mathrm{H}$ is, the larger is the monopoly

\footnotetext{
${ }^{9}$ Shaffer (1982) shows that the $\mathrm{H}$ statistic is also unity for a natural monopoly operating in a perfectly contestable market and also for a sales-maximizing firm that is subject to breakeven constraints
} 
mark-up or the other way round the closer to unity the more competitive is the market. One possible caveat of this approach is that the positive relation between $\mathrm{H}$ and competition may not hold in certain oligopoly equilibria.

The main assumptions of this methodology are (a) firms are operating in their long run equilibrium; (b) firm performance is influenced by the actions of the rest market participants; (c) cost structure is homogeneous; and (d) the price elasticity of demand is greater than unity. The advantage of this method is that it does not require a pirori market definition, therefore it avoids the potential bias caused by the misspecification of market boundaries. Besides, it allows for firm-specific differences in the production function. ${ }^{10}$ It should be noted that the results concerning both perfect and Chamberlinian competition models rely crucially on the assumption that firms are observed in the long-run equilibrium, thus implying that their returns should not be statistically correlated with input prices (assumption a) above). This is not the case for the monopoly model. Fortunately there exists a separate test. For the long equilibrium test, $\mathrm{H}$ statistic must be estimated using the return on assets as the dependent variable in place of the total revenue to balance sheet. A value of zero would prove equilibrium (Shaffer, 1982).

The extension of the Panzar and Rosse (1987) methodology to banking requires assuming that banks are treated as single product firms. This is a usual assumption, consistently with the so-called intermediation approach to banking where banks are viewed mainly as financial intermediaries. The $\mathrm{H}$ statistic has been extensively applied to the banking sector. Shaffer (1982) studies a cross-section of banking firms in New York in 1979, and finds that market cannot be characterized as monopolistic or perfectly competitive in the long run equilibrium. Nathan and Neave (1989) obtain the same results for a sample of Canadian banks, trust companies and mortgage companies during the period 1983-1984. Molyneux et al. (1994) use the same methodology in a sample of German, UK, French, Italian, and Spanish banks for the period 1986-1989. Their results suggest monopolistic competition in Germany, France, Spain and the UK, and monopoly in Italy. Vesala (1995) applies a similar model to the Finnish banking industry and finds monopolistic competition for 1985-1988 and 1991-1992 and perfect competition for 1989-1990. Molyneux et al. (1996) find that Japanese commercial banks present a monopoly situation for 1986 and monopolistic competition for 1988 . Coccorese (1998a) and (2004) for Italy and Hondroyiannis et al. (1999) for Greece

\footnotetext{
${ }^{10}$ Therefore, it allows us to study differences between types of banks (commercial banks versus non-forprofit institutions).
} 
find monopolistic competition. De Bandt and Davis (2000) reported monopolistic competition for large banks and monopoly for small banks of Germany and France, and monopolistic competition for small and large banks in Italy over the period 1992-1996. Bikker and Groeneveld (2000) examine the competitive behaviour of banks in 23 developed countries over the 1988-1999 period. They find that in general terms banking markets in industrialized countries can be characterized by monopolistic competition. Bikker and Haaf (2002) extend the previous work to the analysis of local markets. Ashton (2000) and Drake and Simper (2003) analyse the case of the UK for the 1990-1995 and 1995-2001 periods respectively. Both studies conclude that the monopolistically competitive conduct is present in UK Building Societies and UK banking retail sector as a whole. Maudos and Perez (2003) analyse the Spanish banking sector for the period 1995-2001. They show that Spanish institutions both commercial and savings banks are characterised by monopolistic competition. Koutsomanoli-Filipaki and Staikouras (2004) analyse banking competition in the enlarged EU finding that a certain monopolistic competition is present. Finally in a recent paper, Claessens and Laeven (2004) estimate the $\mathrm{H}$ statistic for 50 countries during the period 19942001 and find that the monopolistic competition is the best description for the degree of competition. Furthermore, they analyse the national factors that may induce this result. Yildirim and Philippatos (2006) analyse the evolution of competitive condition in the banking industries of 14 Central and Easter European transition economies. They show that except for Yugoslavia, Macedonia and Slovakia, the banking sectors analyzed cannot be characterized by the bipolar cases of either perfect competition or monopoly over the period 1993-2000.

Despite the number of papers that analyse the banking sector, it is important to remark that conclusions are not completely comparable as they refer to different time periods. This paper wants to contribute to this debate in three aspects. First, it takes into account the introduction of the European single currency and evaluates its effects on banking competition. Second, it distinguishes among different ownership structures enabling us to highlight which property structure has been more affected by the new scenario. Third, it carries out the analysis of the consequences of the 1997 Building society act in the degree of competition in the UK market.

\section{Methodology and Data}

The main assumption of the paper is that banks are single product firms. This 
assumption is crucial to apply the Panzar and Rosse method. We estimate the following reduced form revenue equation on a panel data set of banks for UK, France, Denmark and Spain separately:

$$
\begin{aligned}
\operatorname{Ln}\left(R E V_{i t}\right) & =\alpha+h_{1} \ln \left(p f_{i t}\right)+h_{2} \ln \left(p l_{i t}\right)+h_{3} \ln \left(p k_{i t}\right)+\beta_{1} \ln \left(\text { tassets }_{i t}\right) \\
& +\alpha_{2} \ln \left(\text { eqty }_{i t}\right)+\alpha_{3} \ln \left(\text { loass }_{i t}\right)+\alpha_{4} \ln \left(\text { intbankdep }_{i t}\right)+\alpha_{i t}
\end{aligned}
$$

where $\mathrm{t}$ is the period, $\mathrm{i}$ is the bank observed and $\ln$ is the natural logarithm.

Due to data availability, the dependent variable $R E V_{\text {it }}$ is the ratio of total gross revenues to total balance sheet. Traditionally, interest revenues have been used as dependent variable. De Bandt and Davis (2000) argue that given the tighter competition environment, the distinction between interest and non interest income becomes less relevant, such that competition is equally vigorous for both. There may also be important complementarities, with both loans and other non interest services, in the context of customer relationships. In particular, banking regulations may lead to cross-subsidisation (Chiappori et al., 1995). Besides, the deregulation processes in the countries analysed make this approach more coherent in terms of data availability. Finally, from a comparative perspective the existence of accounting differences across countries is an additional argument in favour of having a comprehensive view of bank revenues.

There are three input factors considered, namely, deposits, labour and physical capital. $P F$, the unit price of fund is computed by the ratio of interest expenses to deposits and other liabilities, $P L$ is the ratio of personnel expenses to number of employees and accounts for the unit price of labour. $P K$ is the ratio of non-interest expenses to fixed assets and accounts for the price of capital. All these proxies have been previously used in the application of the $H$ statistic to the banking sector.

The $H$ statistic is then the sum of the estimated input coefficients. Therefore, the test for "monopolistic competition" is then:

$$
0<H=\left(h_{1}+h_{2}+h_{3}\right)<1
$$

while $H \leq 0$ is "monopoly" and $H=1$ is "perfect competition".

In order to take into account size, risk and deposit mix differences several control variables are included: total assets (tassets), the ratio of equity to total assets (eqty), the ratio of loans to total assets (loass) and interbank deposits (intbankdep) respectively. The size variable, tassets, accounts both for cost differencies associated to size and for greater diversification, therefore the ex-ante effect of size on bank revenue is not obvious. The coefficient of risk capital, equity 
to asset ratio (eqty) is not obvious a priori either and the loans to total assets ratio (loass) coefficient is expected to be positive because a higher fraction of loans induces higher revenues. The interbank deposits ratio (intbankdep) coefficient is expected to be negative as it is a more expensive source of funds. In banking literature, both plain variables, Molyneux et al. (1994) and Bikker and Groeneveld (2000), and logarithms, De Bandt and Davis (2000) have been used. We consider more appropriate the latter choice as it may help in reducing simultaneity bias.

Having a panel data set, allows us to account for omitted bank-specific variables or time varying factors (e.g. aggregate supply and demand shocks). When there are individual effects, the ordinary least squared estimation (OLS) of the panel data model may produce errors and biases in the coefficient values and can induce a mistake in the serial correlation degree. The specific effects can be treated as fixed or random. The problem is not if effects are fixed or random. The problem is whether these effects are correlated to the observable variables. When effects can be considered random, OLS estimator is consistent but inefficient. Provided that the effects are fixed and correlated with the explanatory variables, the OLS estimator is not consistent. Therefore, to get consistent estimations, the use of an estimator that makes these individual effects disappear is needed. If this is the case, a consistent estimator is the within-group estimator that only cares for the time variation for every sector. However, if the effects are not correlated with the explicative variables, then unconditional inference (random effect estimation) must be done, (Arellano and Bover, 1990). The Hausman test is used to control the potential correlation of the effects; under the null hypothesis the random effect estimator is consistent. Therefore, we apply the fixed effect estimator when the Hausman test is rejected, because individual fixed effects are correlated with the explicative variables. ${ }^{11}$

We first estimate equation (1) for the whole sample. Then, in all countries, we estimate separately the equations for commercial banks and non-for profit institutions. This segmentation allows for the analysis of non-for-profit institutions that are better positioned in certain niches of the market and have a qualitative better public image. Finally, in order to confirm that the Panzar and Rosse statistic provides useful results, we need to determine that the banking systems that we consider are in equilibrium. Therefore, we must verify that input prices are not

\footnotetext{
${ }^{11}$ Heterocedasticity consistent standard errors of the fixed effect estimators were also computed using White's (1980) estimator applied to the data in group mean deviation form. In most cases they turn out to be quite similar to the estimates that are reported in the tables.
} 
Table 1. Sample observations

Number of banks per year, country and type of institution

\begin{tabular}{ccccccccc}
\hline & \multicolumn{2}{c}{ UK } & \multicolumn{2}{c}{ SPAIN } & \multicolumn{2}{c}{ FRANCE } & \multicolumn{2}{c}{ DENMARK } \\
\hline & $\begin{array}{c}\text { Comm } \\
\text { banks }\end{array}$ & $\begin{array}{c}\text { Building } \\
\text { Societies }\end{array}$ & $\begin{array}{c}\text { Comm } \\
\text { banks }\end{array}$ & $\begin{array}{c}\text { Savings } \\
\text { banks }\end{array}$ & $\begin{array}{c}\text { Comm } \\
\text { banks }\end{array}$ & $\begin{array}{c}\text { Savings \& } \\
\text { Mutuals }\end{array}$ & $\begin{array}{c}\text { Comm } \\
\text { banks }\end{array}$ & $\begin{array}{c}\text { Savings } \\
\text { banks }\end{array}$ \\
\hline 1996 & 164 & 66 & 108 & 79 & 208 & 145 & 56 & 33 \\
1997 & 168 & 61 & 119 & 85 & 209 & 145 & 55 & 36 \\
1998 & 163 & 64 & 114 & 86 & 209 & 145 & 55 & 37 \\
1999 & 152 & 62 & 115 & 90 & 208 & 145 & 53 & 40 \\
2000 & 142 & 63 & 104 & 86 & 194 & 131 & 54 & 40 \\
2001 & 123 & 61 & 100 & 84 & 177 & 131 & 52 & 34 \\
2002 & 48 & 32 & 99 & 82 & 116 & 78 & 45 & 25 \\
\hline
\end{tabular}

correlated with industry returns.

\section{A. Data}

We use bank-level financial statements data from BANKSCOPE (IBCA) for UK, Denmark, France and Spain for the period 1996-2002. Starting from a large dataset of banks, we arrive, after excluding banks with only one observation and those that do not report all relevant items to an unbalanced panel. Table 1 presents the distribution of the data across the period and main type of institutions analysed.

The sample contains data from commercial banks, saving banks, cooperative banks, building societies, investment banks, and other financial institutions. As said above, in the first step of the analysis we include all the types available. Afterwards, we restrict to the two most important types in UK, France, Denmark and Spain, commercial banks on one side and mutual banks, savings banks and building societies on the other. Despite their different scope in the past, the present activity of building societies, mutual banks and savings banks is similar. All of them can be considered as non profit organizations in the sense of Hansmann (1996), even though the former are mutual type institutions and the latter have a social contribution objective. These institutions are also centre of intense debates due to their ownership structures and their particular governance mechanism. The relevance of these institutions in the national economies makes the separate analysis very interesting. Table 2 presents the summary statistics. 
Table 2. Summary statistics

iotrer is total gross revenue to total balance sheet, $p f$ is the unit price of fund computed by the ratio of interest expenses to deposits and other liabilities, $p l$ is the ratio of personnel expenses to number of employees and accounts for the unit price of labour. Lnpk is the ratio of non-interest expenses to fixed assets and accounts for the price of capital. The control variables: tassets is total assets, loan is the ratio of loans to total assets, eq ty the equity to asset ratio and the interbank deposits ratio is intbankdep.

\begin{tabular}{|c|c|c|c|c|}
\hline \multirow[t]{9}{*}{ UK } & Variable & Mean & Median & Std. Dev. \\
\hline & totrev & 0.046 & 0.0274 & 0.091 \\
\hline & $p f$ & 0.041 & 0.0410 & 0.034 \\
\hline & $p l$ & 0.156 & 0.0416 & 1.409 \\
\hline & $p k$ & 7.566 & 0.9136 & 64.70 \\
\hline & loass & 0.411 & 0.3394 & 0.327 \\
\hline & eqty & 0.185 & 0.0748 & 0.249 \\
\hline & intbankdep & 0.190 & 0.1047 & 0.209 \\
\hline & tassets & 13681 & 1238.2 & 50153 \\
\hline \multirow[t]{9}{*}{ Spain } & Variable & Mean & Median & Std. Dev. \\
\hline & totrev & 0.04 & 0.0374 & 0.025 \\
\hline & $p f$ & 0.037 & 0.0287 & 0.024 \\
\hline & $p l$ & 0.044 & 0.0427 & 0.013 \\
\hline & $p k$ & 1.09 & 0.5180 & 2.985 \\
\hline & loass & 0.520 & 0.5558 & 0.238 \\
\hline & eqty & 0.121 & 0.0712 & 0.168 \\
\hline & intbankdep & 0.197 & 0.1013 & 0.231 \\
\hline & tassets & 9880 & 2585.6 & 29890 \\
\hline \multirow[t]{9}{*}{ France } & Variable & Mean & Median & Std. Dev. \\
\hline & totrev & 0.045 & 0.0380 & 0.073 \\
\hline & $p f$ & 0.052 & 0.0381 & 0.058 \\
\hline & $p l$ & 0.186 & 0.0558 & 2.601 \\
\hline & $p k$ & 0.9140 & 0.000 & 5.705 \\
\hline & loass & 51.96 & 56.27 & 28.98 \\
\hline & eqty & 0.095 & 0.0663 & 0.487 \\
\hline & intbankdep & 0.338 & 0.2461 & 0.283 \\
\hline & tassets & 14613 & 1634.9 & 57153 \\
\hline \multirow[t]{9}{*}{ Denmark } & Variable & Mean & Median & Std. Dev. \\
\hline & totrev & 0.055 & 0.0579 & 0.038 \\
\hline & $p f$ & 0.029 & 0.0259 & 0.016 \\
\hline & $p l$ & 0.434 & 0.3900 & 0.409 \\
\hline & $p k$ & 0.3274 & 0.000 & 1.842 \\
\hline & loass & 55.52 & 58.08 & 18.32 \\
\hline & eqty & 0.131 & 0.125 & 0.090 \\
\hline & intbankdep & 0.101 & 0.0453 & 0.144 \\
\hline & tassets & 25493 & 1505.85 & 91945 \\
\hline
\end{tabular}


Table 3. Equilibrium Test

The dependent variable, Lnroa is return on assets. Independent variables are lnpf, which is the unit price of fund computed by the ratio of interest expenses to deposits and other liabilities, enpe that is the ratio of personnel expenses to number of employees and accounts for the unit price of labour and enpk is the ratio of non-interest expenses to fixed assets and accounts for the price of capital. Furthermore, we include some controls: Intassets, total assets, Inloass, the ratio of loans to total assets, Ineqty, equity to asset ratio and the interbank deposits ratio, lnintbankdep.

\begin{tabular}{lllllll}
\hline & \multicolumn{3}{c}{ Panel A: UK } & \multicolumn{3}{c}{ Panel B: Spain } \\
\hline Lnpf & $1996-2002$ & $1996-1998$ & $1999-2002$ & $1996-2002$ & $1996-1998$ & $1999-2002$ \\
& 0.01818 & -0.06854 & $0.15372 * * *$ & -0.04592 & -0.06878 & -0.00607 \\
Lnpl & {$[0.04155]$} & {$[0.11833]$} & {$[0.05617]$} & {$[0.03465]$} & {$[0.07424]$} & {$[0.04238]$} \\
& $0.17061 * *$ & 0.04673 & 0.04834 & $0.10641 * * *$ & 0.11966 & $0.10994 * *$ \\
Lnpk & {$[0.07386]$} & {$[0.20378]$} & {$[0.11167]$} & {$[0.03771]$} & {$[0.08311]$} & {$[0.05158]$} \\
& -0.04053 & $-0.29704 * * *$ & -0.03546 & 0.05712 & $0.09646 *$ & 0.01417 \\
Lnloass & {$[0.02790]$} & {$[0.06900]$} & {$[0.04738]$} & {$[0.03521]$} & {$[0.05256]$} & {$[0.05758]$} \\
& -0.02764 & -0.02715 & -0.02198 & $-0.33572 * * *$ & -0.13078 & $-0.42739 * *$ \\
Lneqty & {$[0.03950]$} & {$[0.09304]$} & {$[0.06890]$} & {$[0.07035]$} & {$[0.12854]$} & {$[0.14996]$} \\
& $0.13292 * *$ & $0.77952 * * *$ & $0.27611 *$ & $0.23533 * * *$ & 0.14780 & $0.22957 * * *$ \\
Lnintbankdep & 0.00300 & 0.00546 & $-0.05614 * *$ & -0.01666 & -0.00180 & $0.04984 *$ \\
& {$[0.01656]$} & {$[0.04073]$} & {$[0.02580]$} & {$[0.01362]$} & {$[0.01598]$} & {$[0.02573]$} \\
Lntassets & 0.06387 & $0.48848 * * *$ & $0.38694 * * *$ & $-0.33054 * * *$ & $-0.24901 * *$ & $-0.27225 * *$ \\
& {$[0.05363]$} & {$[0.18763]$} & {$[0.12443]$} & {$[0.05595]$} & {$[0.11862]$} & {$[0.10383]$} \\
Constant & $1.14769 * *$ & -0.95011 & -1.37079 & $4.06974 * * *$ & $3.40338 * * *$ & $3.95064 * * *$ \\
& {$[0.47665]$} & {$[1.35411]$} & {$[0.91823]$} & {$[0.45115]$} & {$[0.91809]$} & {$[0.97293]$} \\
\hline Observations & 949 & 456 & 493 & 306 & 156 & 150 \\
\hline R-squared & 0.05 & 0.14 & 0.09 & 0.42 & 0.42 & 0.30 \\
\hline Hausman test & 57.15 & 42.80 & 53.50 & 64.69 & 18.70 & 38.34 \\
(p-value) & $(0.000)$ & $(0.000)$ & $(0.000)$ & $(0.000)$ & $(0.027)$ & $(0.000)$ \\
\hline He & 0.1482 & 0.3188 & -0.0354 & 0.1176 & 0.1473 & 0.1180 \\
Ho & 2.97 & 2.15 & 1.75 & 3.43 & 1.71 & 1.31 \\
\hline Standard & {$[0.18845]$} & {$[0.14493]$} & {$[0.05082]$} & {$[0.13652]$} & {$[0.07493]$} \\
\hline
\end{tabular}

Standard errors in brackets. *significant at $10 \%$; **significant at $5 \%$; *** significant at $1 \%$. H0: $F$ statistic for testing the hypothesis $\mathrm{H}=0$, c: significant at $10 \%$; b: significant at $5 \%$ and a: significant at $1 \%$

\section{Empirical Results}

Empirical results appear in Tables 4 to 7 for UK, Spain, Denmark and France

\footnotetext{
${ }^{12}$ The euro has been a feature of the financial landscape since 1 January 1999, when the third stage of EMU began. On 1 January 1999, the exchange rates of the participating currencies were irrevocably set, Euro area Member States began implementing a common monetary policy and the euro was introduced as a legal currency. The 11 currencies of the participating Member States became subdivisions of the euro. Therefore, the periods analyzed are 1996-1998 and 1999-2002.
} 
Table 3. Continued

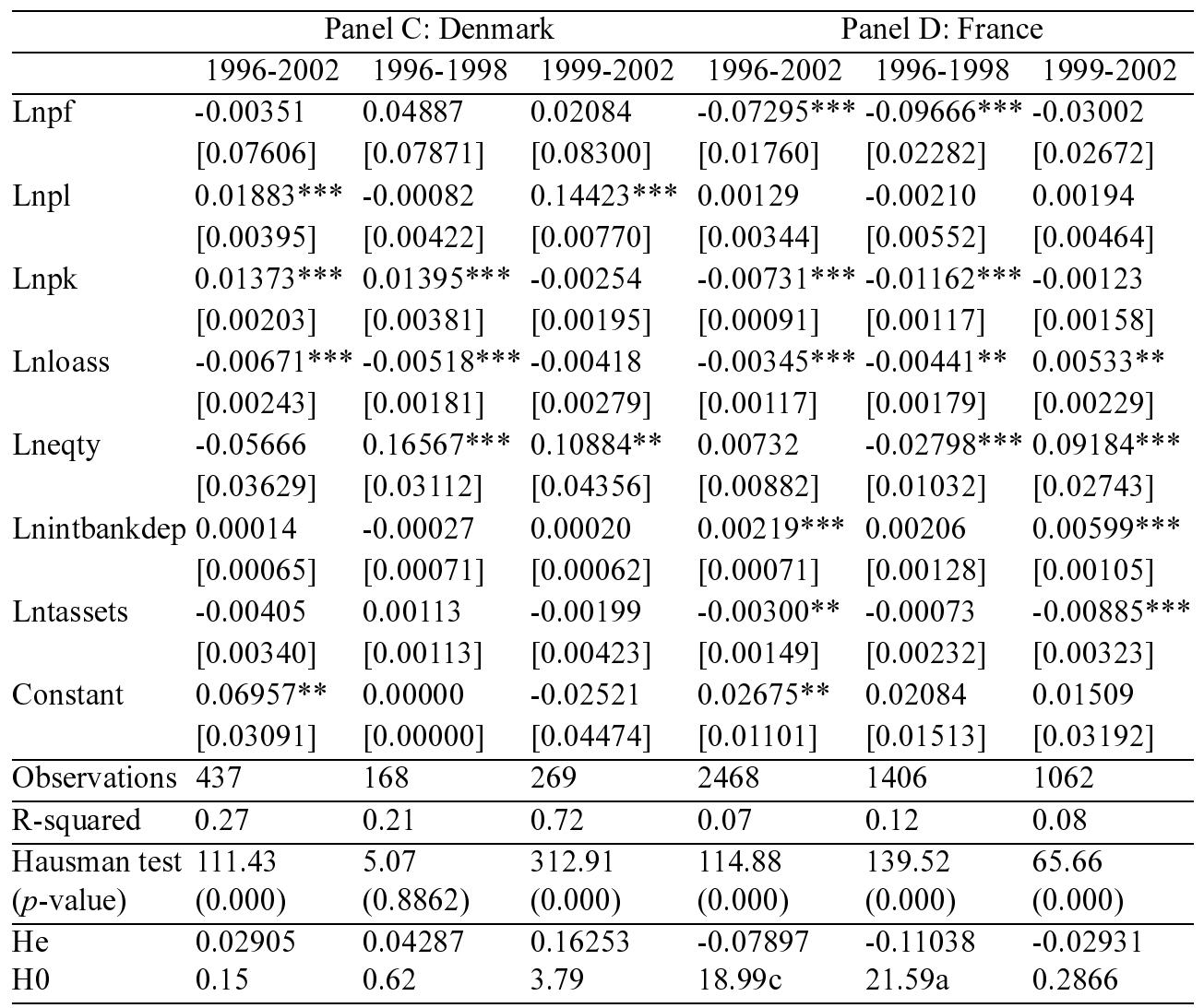

respectively. Panel A of each table collects results for the whole sample, panel B those for commercial banks and finally panel $\mathrm{C}$ the respective for the non-profit credit institutions. For each country and sample, we have estimated the equation for the whole period and for two subperiods: the pre-EMU and post-EMU period. This different estimation allows us to assess whether there has been any change in competitive conditions associated to the adoption of the EMU. ${ }^{12}$ Since the $\mathrm{H}$ statistic is only valid if the market is in equilibrium, we do the equilibrium test. To implement such a test, we compute the following equation for each country:

$$
\begin{aligned}
\operatorname{Ln}\left(\text { roa }_{\mathrm{it}}\right) & =\alpha+\mathrm{h}_{1} \ln \left(p f_{\mathrm{it}}\right)+\mathrm{h}_{2} \ln \left(p l_{\mathrm{it}}\right)+\mathrm{h}_{3} \ln \left(\mathrm{pk}_{\mathrm{it}}\right)+\beta_{1} \ln \left(\text { tassets }_{\mathrm{it}}\right) \\
& +\beta_{2} \ln \left(\text { eqty }_{\mathrm{it}}\right)++\beta_{3} \ln \left(\text { loass }_{\mathrm{it}}\right)+\beta_{4} \ln \left(\text { intbankdep }_{\mathrm{it}}\right)+\varepsilon_{\mathrm{it}}
\end{aligned}
$$

where roa is the pre-tax return on assets. Because ROA can take on small negative values, following Claessens and Laeven (2004), we compute the dependent variable as roal $=1+r o a$, where roa is the unadjusted return on assets. 
Table 4. Market results for uk

The dependent variable, Lntotrev is total gross revenue to total balance sheet. Independent variables are lnpf, which is the unit price of fund computed by the ratio of interest expenses to deposits and other liabilities, lnpl that is the ratio of personnel expenses to number of employees and accounts for the unit price of labour and lnpk is the ratio of non-interest expenses to fixed assets and accounts for the price of capital. Furthermore, we include some controls: Intassets, total assets, lnloass, the ratio of loans to total assets, lneqty, equity to asset ratio and the interbank deposits ratio, lnintbankdep.

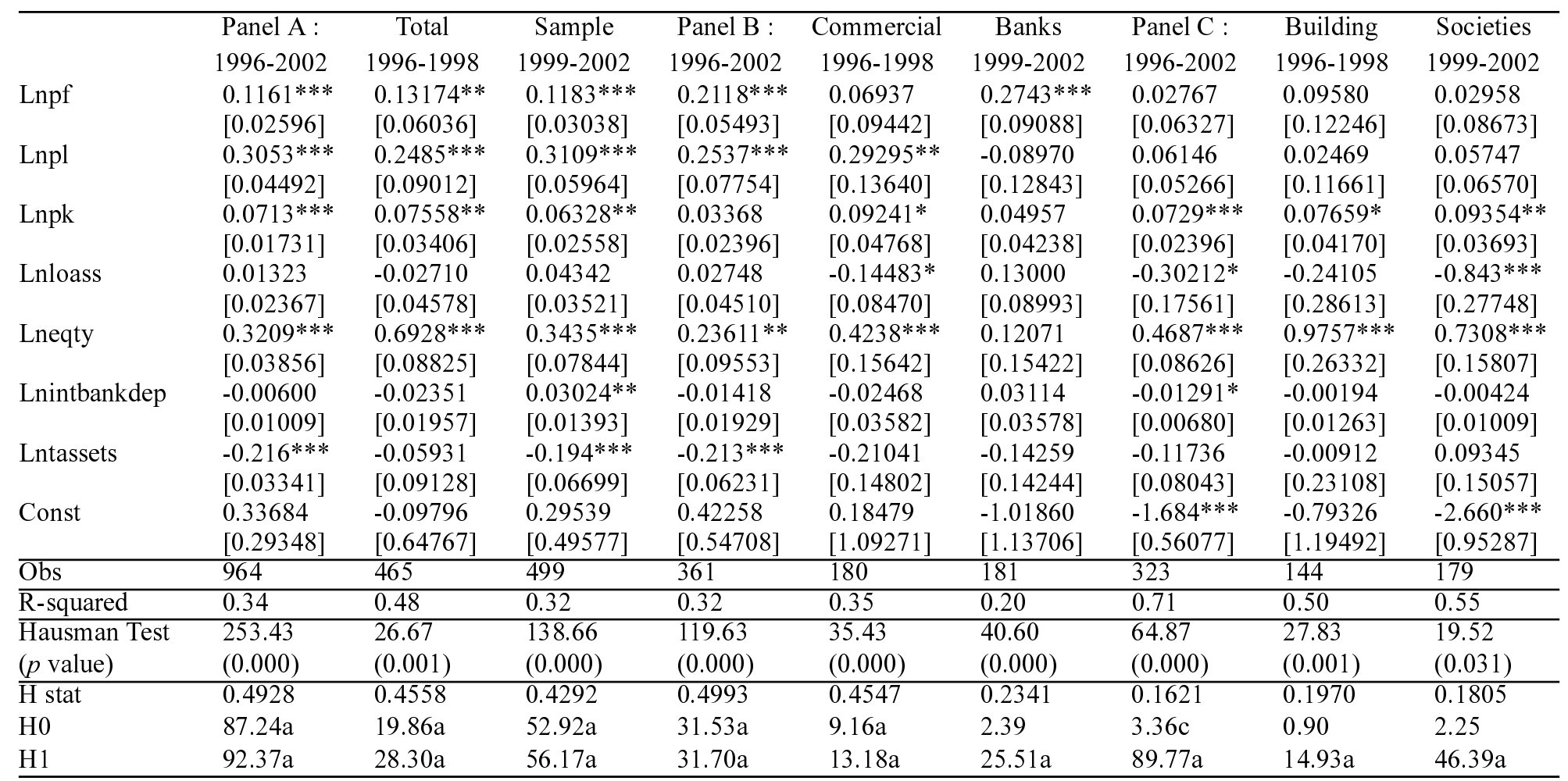

Standard errors in brackets. * significant at $10 \% ; * *$ significant at $5 \%$; *** significant at $1 \%$.

$\mathrm{H} 1: F$ statistic for testing the hypothesis $\mathrm{H}=1 ; \mathrm{H} 0: F$ statistic for testing the hypothesis $\mathrm{H}=0$. c: significant at $10 \%$; b: significant at $5 \%$ and a: significant at $1 \%$ 
We define the equilibrium $\mathrm{H}_{\mathrm{E}}$ statistic as $h 1+h 2+h 3$. We test whether $H_{E}=0$, using a $F$-test. If rejected, the market is assumed not to be in equilibrium. Table 3 shows the results for all countries for the whole period and the two sub-periods.

In general terms, there is no evidence against the hypothesis that the $\mathrm{H}_{\mathrm{E}}$ statistic is equal to zero at the 5 per cent level. Therefore, data appear to be in equilibrium. As pointed out by De Bandt and Davis (2000), this "equilibrium" does not mean that competitive conditions do not change, an assumption which would contradict the period considered, characterised by a process of structural changes. It only implies that changes in banking industries in the countries selected are taken as gradual. The test has been realised also considering commercial banks and nonprofit institutions separately and the results again proved that the markets are in equilibrium. $^{13}$

As it can be seen in Tables 4 to 7 , the coefficient of all factor prices tends to be positive or zero for all countries in the different specifications estimated. The positive or zero sign for the unit cost of labour contrasts with previous results that obtained a negative sign instead. ${ }^{14}$ A possible explanation may be the deregulation of labour markets during the nineties, especially in Spain. The signs of the control variables are very consistent along the different realisations, although there are some variations in the significance level. The size variable is negative and significant; therefore smaller financial institutions present higher revenues. The ratio of deposits is negative, as expected, but not always significant. The coefficients of the equity to assets ratio and loan to assets are positive, but not always significant either.

Looking at the $\mathrm{H}$-tests, the data shows that the values of $\mathrm{H}$ are significantly nonnegative for all countries except for the case of France. Going through the results of the whole sample for the UK (Table 4, panel A), it can be observed that monopolistic competition seems to characterise the structure of the UK banking

\footnotetext{
${ }^{13}$ These results are not shown for brevity, but are available from the authors upon request. Only commercial banks for the period 99-02 seem to be characterised by disequilibrium in UK, Spain and France.

${ }^{14}$ Molyneux at al (1994) and De Bandt and Davis (2000), for the mid 1980's and mid 1990's respectively.

${ }^{15}$ This result is also obtained with the interest revenues as dependent variable.

${ }^{16}$ It can be shown that under stronger assumptions, in particular a constant price elasticity of demand across bank markets and countries, the continuous interpretation of $\mathrm{H}$ and the comparison between markets is correct.
} 
Table 5. Market results for spain

The dependent variable, Lntotrev is total gross revenue to total balance sheet. Independent variables are lnpf, which is the unit price of fund computed by the ratio of interest expenses to deposits and other liabilities, lnpl that is the ratio of personnel expenses to number of employees and accounts for the unit price of labour and lnpk is the ratio of non-interest expenses to fixed assets and accounts for the price of capital. Furthermore, we include some controls: Intassets, total assets, Inloass, the ratio of loans to total assets, Ineqty, equity to asset ratio and the interbank deposits ratio, lnintbankdep.

\begin{tabular}{|c|c|c|c|c|c|c|c|c|c|}
\hline & \multicolumn{3}{|c|}{ Panel A: Total Sample } & \multicolumn{3}{|c|}{ Panel B: Commercial Banks } & \multicolumn{3}{|c|}{ Panel C: Savings Banks } \\
\hline & $1996-2002$ & 1996-1998 & 1999-2002 & $1996-2002$ & 1996-1998 & $1999-2002$ & $1996-2002$ & 1996-1998 & $1999-2002$ \\
\hline \multirow[t]{2}{*}{$\overline{\operatorname{Lnpf}}$} & $0.1985 * * *$ & $0.2451 * * *$ & $0.06560 *$ & $0.2648 * * *$ & $0.3099 * * *$ & 0.06963 & $0.1065^{* *}$ & 0.10933 & 0.01016 \\
\hline & [0.0293] & {$[0.0595]$} & {$[0.0382]$} & {$[0.0430]$} & {$[0.0932]$} & {$[0.0470]$} & {$[0.0440]$} & {$[0.0937]$} & {$[0.0624]$} \\
\hline \multirow[t]{2}{*}{ Lnpl } & $0.0834 * * *$ & $0.1416^{* *}$ & $0.1331 * * *$ & $0.3006^{* * *}$ & 0.03623 & $0.5721 * * *$ & 0.06611 & 0.10904 & $0.28527^{*}$ \\
\hline & [0.0319] & {$[0.0666]$} & [0.0465] & {$[0.0900]$} & [0.1194] & {$[0.1207]$} & {$[0.0584]$} & {$[0.0761]$} & {$[0.1610]$} \\
\hline \multirow[t]{2}{*}{ Lnpk } & 0.01249 & $0.1306^{* * *}$ & 0.04708 & $0.16407 * *$ & $0.4238 * * *$ & 0.09111 & -0.01076 & -0.04084 & 0.17257 \\
\hline & {$[0.0298]$} & {$[0.0421]$} & {$[0.0520]$} & {$[0.0801]$} & {$[0.1084]$} & [0.1099] & {$[0.0407]$} & {$[0.0600]$} & {$[0.1148]$} \\
\hline \multirow[t]{2}{*}{ Lnloass } & $0.2931 * * *$ & $0.2399 * *$ & 0.06982 & $0.3335^{* * *}$ & $0.3377 * *$ & 0.19175 & $0.2220 * * *$ & 0.26120 & 0.08491 \\
\hline & {$[0.0596]$} & {$[0.1030]$} & {$[0.1354]$} & {$[0.1205]$} & {$[0.1382]$} & {$[0.1686]$} & {$[0.0793]$} & {$[0.1601]$} & [0.2045] \\
\hline \multirow[t]{2}{*}{ Lneqty } & $0.08374^{*}$ & $0.4410 * * *$ & 0.02705 & -0.03601 & -0.00204 & $0.2997 * *$ & $0.2706^{* * *}$ & 0.26114 & 0.08713 \\
\hline & {$[0.0430]$} & {$[0.1094]$} & {$[0.0676]$} & {$[0.0861]$} & [0.1995] & {$[0.1310]$} & {$[0.0645]$} & {$[0.1609]$} & {$[0.1207]$} \\
\hline \multirow[t]{2}{*}{ Lnintbankdep } & $-0.0268 * *$ & $-0.034 * * *$ & 0.00269 & $-0.121 * * *$ & $-0.119 * * *$ & -0.03196 & $-0.02098 *$ & $-0.0294 * *$ & -0.00893 \\
\hline & {$[0.0115]$} & {$[0.0128]$} & {$[0.0232]$} & {$[0.0344]$} & {$[0.0336]$} & [0.0499] & {$[0.0112]$} & {$[0.0130]$} & {$[0.0325]$} \\
\hline \multirow[t]{2}{*}{ Lntassets } & $-0.397 * * *$ & -0.10516 & $-0.695 * * *$ & $-0.347 * * *$ & -0.0891 & $-0.458 * * *$ & $-0.435^{* * *}$ & $-0.437 * * *$ & $-0.4210^{*}$ \\
\hline & {$[0.0474]$} & {$[0.0950]$} & {$[0.0937]$} & {$[0.0851]$} & {$[0.2020]$} & {$[0.1271]$} & {$[0.0881]$} & {$[0.1425]$} & {$[0.2370]$} \\
\hline \multirow[t]{2}{*}{ Constant } & $1.5162 * * *$ & 0.35019 & $3.6796^{* * *}$ & $1.8576^{* * *}$ & -0.84741 & $4.076^{* * *}$ & $1.9306^{* *}$ & $2.0444 * *$ & 1.71046 \\
\hline & [0.4143] & {$[0.7358]$} & {$[0.8788]$} & {$[0.6629]$} & [1.6059] & [1.4521] & {$[0.7569]$} & [1.0026] & [2.3392] \\
\hline$\overline{\mathrm{Obs}}$ & 306 & 156 & 150 & 92 & 44 & 48 & 168 & 88 & 80 \\
\hline R-squared & 0.77 & 0.68 & 0.78 & 0.84 & 0.87 & 0.93 & 0.85 & 0.78 & 0.73 \\
\hline Hausman test & 144.16 & 261.46 & 60.93 & 31.27 & 26.71 & 26.79 & 101.84 & 35.70 & 22.81 \\
\hline ( $p$ value) & $(0.000)$ & $(0.000)$ & $(0.000)$ & $(0.000)$ & $(0.000)$ & $(0.000)$ & $(0.000)$ & $(0.000)$ & $(0.011)$ \\
\hline H stat & 0.2944 & 0.5175 & 0.2458 & 0.7295 & 0.7101 & 0.7328 & 0.1618 & 0.1775 & 0.468 \\
\hline Ho & $29.94 a$ & $32.76 a$ & $6.98 \mathrm{a}$ & $29.68 \mathrm{a}$ & $32.94 a$ & $11.75 \mathrm{a}$ & $3.80 \mathrm{c}$ & 1.76 & $5.01 b$ \\
\hline $\mathrm{H} 1$ & $171.87 \mathrm{a}$ & $28.47 \mathrm{a}$ & $65.73 a$ & $4.08 \mathrm{~b}$ & 2.94 & 1.56 & $101.83 \mathrm{a}$ & $37.69 \mathrm{a}$ & $6.67 b$ \\
\hline
\end{tabular}

Standard errors in brackets. significant at $10 \% \cdot * *$ significant at $5 \% \cdot * * *$ significant at $1 \%$

$\mathrm{H} 1: F$ statistic for testing the hypothesis $\mathrm{H}=1$; $\mathrm{H} 0: F$ statistic for testing the hypothesis $\mathrm{H}=0$. c: significant at $10 \%$; b: significant at $5 \%$ and a: significant at $1 \%$ 
sector. ${ }^{15}$ Interpreting $\mathrm{H}$ statistic as a continuous measure, in the spirit of Bikker and Haaf (2002), ${ }^{16}$ results show a decreasing competitive environment for the period considered, as the magnitude of the $\mathrm{H}$ statistic in the post-EMU period is $5.8 \%$ smaller than that estimated for the previous period.

This trend is much sharper if we look at commercial banks with a reduction of 48.5 per cent (panel B). In fact, in this latter case, we cannot reject that the $\mathrm{H}$ statistic is significantly different from zero in the post EMU period. The same result is obtained for non-profit institutions (panel $\mathrm{C}$ ), indicating that both commercial banks and building societies are operating in a monopoly situation. In any case, if we compare the two different institutions, it should be noted that commercial banks seem to work in a more competitive environment than non-for profit institutions. However, the distance between them decreases in more than one third along the period. This reduction is not because Building societies improve their competitiveness, but because commercial bank sector worsens its competitive position.

These results show that the UK banking sector has not become more competitive in the period analysed at all. The distinction between commercial banks and building societies helps in revealing a difference in terms of competitive environment. Each type of institution enjoys a monopoly situation instead of a monopolistic competition. Deregulation of Building societies in 1997 has not increased competition. Similar results are obtained by Drake and Simper (2003) for the 1995-2001 period. A possible explanation of this interesting result is that the recent regulation changes has provoked tensions in the system and caused destabilising effects on corporate governance (Cook et. al. 2001). In this sense, it is interesting to point out that the converted building societies failed to match their historical market shares in both the mortgage and savings market in $2000 .^{17}$ Furthermore, the introduction of the single currency does not enhance competitiveness via increased cross border competition either.

For Spain (Table 5), H statistics are significantly different from unity and zero for the whole sample (panel A), therefore the Spanish financial market is characterised by monopolistic competition. The value of the $\mathrm{H}$ statistic in the last part of the sample 1999-2002 is smaller than in the first subperiod 1996-98. Therefore, the introduction of the EMU does not seem to have a beneficial effect on competitive conditions, at least in the banking sector as a whole. Furthermore, the value of the $\mathrm{H}$ statistic is lower than that estimated for the UK, meaning that

\footnotetext{
${ }^{17}$ Building Societies Association (2000).
} 
the competitive conditions of the Spanish banking system are not as demanding as in the UK.

The analysis of commercial banks and non-profit institutions separately seeds some light and stresses the importance of analysing shareholder-owned institutions and non-for profit individually. Spanish commercial banks enjoy monopolistic competition when we consider the whole period. Instead, the analysis for the subperiods reveals that Spanish commercial banks present perfect competition. Furthermore, the post EMU H-statistic increases 3.2 per cent. Therefore, EMU has had a positive effect on competition for Spanish commercial banks. Maudos and Perez (2003) conclude that monopolistic competition is the best market representation for the Spanish banking market during 1995-2001. Henceforth, the enlargement of the period of study and the consideration of the adoption of the single currency provide additional evidence on the evolution of competitive conditions of Spanish commercial bank sector.

$\mathrm{H}$ statistic for Spanish saving banks suggests monopolistic competition. Moreover, H statistic increases 26.3 per cent in the post-Euro period. Although non-profit institutions operate in a less competitive environment and maintain a certain degree of market power, differences with commercial banks reduce significantly along the period. These results for the Spanish saving banks extend the evidence obtained by Maudos and Perez (2003).

In the case of Denmark, results of the whole sample (Table 6, panel A), indicate that a competitive market seems to characterise the structure of the Danish banking sector. The evolution of the $\mathrm{H}$ statistic shows a decreasing competitive environment for the period considered, approaching the monopolistic competition market. This trend is mainly due to the evolution of savings banks as the situation of commercial banks is much more stable. In fact, in this latter case, and contrary to the result of savings banks, we cannot reject that the $\mathrm{H}$ statistic is significantly different from one in the post EMU period. Therefore, savings banks face a less competitive environment.

These results show that the Danish banking sector has not become more competitive in the period analysed at all. However, the distinction between commercial banks and savings banks helps in revealing a difference in terms of competitive environment. Commercial banks place themselves between a competitive outcome and the monopolistic competition whereas savings banks evolve clearly to a less competitive situation after the EMU.

For France (Table 7), H statistics are significantly different from unity and zero 
Table 6. Market results for denmark

The dependent variable, Lntotrev is total gross revenue to total balance sheet. Independent variables are lnpf, which is the unit price of fund computed by the ratio of interest expenses to deposits and other liabilities, lnpl that is the ratio of personnel expenses to number of employees and accounts for the unit price of labour and lnpk is the ratio of non-interest expenses to fixed assets and accounts for the price of capital. Furthermore, we include some controls: Intassets, total assets, Inloass, the ratio of loans to total assets, lneqty, equity to asset ratio and the interbank deposits ratio, lnintbankdep.

\begin{tabular}{|c|c|c|c|c|c|c|c|c|c|}
\hline & \multicolumn{3}{|c|}{ Panel A: Total Sample } & \multicolumn{3}{|c|}{ Panel B: Commercial Banks } & \multicolumn{3}{|c|}{ Panel C: Savings Banks } \\
\hline & $1996-2002$ & 1996-1998 & $1999-2002$ & 1996-2002 & 1996-1998 & $1999-2002$ & $1996-2002$ & 1996-1998 & $1999-2002$ \\
\hline & Intotrev & Lntotrev & Intotrev & Intotrev & Intotrev & Intotrev & Intotrev & Intotrev & Intotrev \\
\hline \multirow{2}{*}{$\operatorname{Lnpf}$} & $0.92048 * * *$ & $0.81625 * * *$ & $0.35266^{*}$ & $1.31005 * * *$ & $0.80037 * * *$ & $0.67108 * *$ & -0.19318 & 0.07374 & -0.00862 \\
\hline & {$[0.14308]$} & [0.12478] & [0.18137] & [0.15805] & {$[0.08620]$} & {$[0.27601]$} & [0.19732] & {$[0.48470]$} & [0.19111] \\
\hline \multirow[t]{2}{*}{ Lnpl } & $0.02195 * * *$ & 0.00087 & $0.26476 * * *$ & 0.03992 & 0.01461 & $0.11880^{* * *}$ & -0.02654 & -0.02182 & $0.05041 *$ \\
\hline & {$[0.00743]$} & {$[0.00590]$} & {$[0.01683]$} & {$[0.02644]$} & {$[0.01899]$} & {$[0.03840]$} & {$[0.02079]$} & {$[0.03789]$} & {$[0.02770]$} \\
\hline \multirow[t]{2}{*}{ Lnpk } & $0.03595 * * *$ & $0.05869 * * *$ & 0.00612 & $0.03254 * * *$ & $0.02345 * * *$ & $0.01115^{*}$ & 0.00426 & 0.01046 & $0.00519^{* *}$ \\
\hline & {$[0.00382]$} & {$[0.00784]$} & {$[0.00426]$} & {$[0.00474]$} & {$[0.00594]$} & {$[0.00664]$} & {$[0.00284]$} & {$[0.01781]$} & {$[0.00237]$} \\
\hline \multirow[t]{2}{*}{ Lnloass } & $-0.01100 * *$ & $-0.03580 * * *$ & 0.00455 & 0.00005 & $-0.02179 * * *$ & -0.00235 & -0.00109 & -0.00513 & $0.01822 * * *$ \\
\hline & {$[0.00456]$} & {$[0.00396]$} & {$[0.00610]$} & {$[0.00548]$} & {$[0.00455]$} & {$[0.00715]$} & {$[0.00514]$} & {$[0.01204]$} & [0.00599] \\
\hline \multirow[t]{2}{*}{ Lneqty } & $0.31928 * * *$ & -0.12031 & $0.89095 * * *$ & $0.51328 * * *$ & -0.01007 & $1.12506 * * *$ & $0.18451 * * *$ & $0.20812^{* *}$ & $0.20218 * * *$ \\
\hline & [0.06827] & {$[0.08705]$} & [0.09519] & [0.08164] & {$[0.06053]$} & [0.13449] & {$[0.03684]$} & {$[0.08262]$} & [0.04162] \\
\hline \multirow[t]{2}{*}{ Lnintbankdep } & 0.00045 & -0.00029 & $0.00268 * *$ & -0.00101 & $-0.00172 *$ & 0.00215 & 0.00056 & 0.00041 & 0.00088 \\
\hline & {$[0.00122]$} & {$[0.00122]$} & {$[0.00136]$} & {$[0.00149]$} & [0.00094] & {$[0.00186]$} & {$[0.00062]$} & {$[0.00120]$} & {$[0.00076]$} \\
\hline \multirow[t]{2}{*}{ Lntassets } & $-0.02796 * * *$ & $-0.03085 * * *$ & $-0.04261 * * *$ & $-0.01870 * * *$ & $-0.02268 * * *$ & $-0.02514 * *$ & $-0.00281 *$ & -0.00259 & $-0.00441^{* *}$ \\
\hline & {$[0.00640]$} & {$[0.00686]$} & [0.00924] & [0.00699] & {$[0.00495]$} & {$[0.01187]$} & {$[0.00160]$} & {$[0.00233]$} & {$[0.00172]$} \\
\hline \multirow[t]{2}{*}{ Constant } & $0.22949 * * *$ & $0.40996^{* * *}$ & $0.17862 *$ & $0.12106^{*}$ & $0.29672 * * *$ & 0.09110 & $0.06560 * * *$ & 0.00000 & 0.00000 \\
\hline & {$[0.05815]$} & [0.06462] & {$[0.09777]$} & {$[0.06881]$} & [0.04857] & [0.12017] & {$[0.02332]$} & {$[0.00000]$} & {$[0.00000]$} \\
\hline$\overline{\text { Obs }}$ & 437 & 168 & 269 & 293 & 114 & 179 & 86 & 32 & 54 \\
\hline R-squared & 0.52 & 0.77 & 0.77 & 0.67 & 0.85 & 0.80 & 0.55 & 0.56 & 0.81 \\
\hline Hausman test & 27.40 & 0.8152 & 474.79 & 50.61 & 181.19 & 129.80 & 6.69 & 2.78 & 8.62 \\
\hline ( $p$ value) & $(0.032)$ & $(0.000)$ & $(0.000)$ & $(0.000)$ & $(0.000)$ & $(0.000)$ & $(0.9460)$ & $(0.9861)$ & $(0.5688)$ \\
\hline H stat & 0.9783 & 0.8758 & 0.6235 & 1.3825 & 0.8384 & 0.8010 & -0.2115 & 0.0623 & 0.047 \\
\hline H0 & $46.57 \mathrm{a}$ & $49.62 \mathrm{a}$ & $11.68 \mathrm{a}$ & $71.75 \mathrm{a}$ & $109.89 a$ & $8.09 \mathrm{a}$ & $37.04 \mathrm{a}$ & $3.67 \mathrm{~b}$ & $23.04 \mathrm{a}$ \\
\hline H1 & 0.02 & 1.00 & $4.26 b$ & $5.80 \mathrm{~b}$ & $4.08 \mathrm{~b}$ & 0.50 & 1.16 & 0.02 & 0.06 \\
\hline
\end{tabular}

Standard errors in brackets. $*$ significant at $10 \% ; * *$ significant at $5 \%$; ${ }^{* *}$ stistic for testing the hypothesis $\mathrm{H}=1 ; \mathrm{H} 0: F$ statistic for testing the hypothesis $\mathrm{H}=0$. c: significant at $10 \%$; b: significant at $5 \%$ and a: significant at $1 \%$ 
Table 7. Market results for france

The dependent variable, Lntotrev is total gross revenue to total balance sheet. Independent variables are lnpf, which is the unit price of fund computed by the ratio of interest expenses to deposits and other liabilities, Inpl that is the ratio of personnel expenses to number of employees and accounts for the unit price of labour and lnpk is the ratio of non-interest expenses to fixed assets and accounts for the price of capital. Furthermore, we include some controls: Intassets, total assets, Inloass, the ratio of loans to total assets, lneqty, equity to asset ratio and the interbank deposits ratio, lnintbankdep.

\begin{tabular}{|c|c|c|c|c|c|c|c|c|c|}
\hline & \multicolumn{3}{|c|}{ Panel A: Total Sample } & \multicolumn{3}{|c|}{ Panel B: Commercial Banks } & \multicolumn{3}{|c|}{ Panel C: Savings Banks } \\
\hline & 1996-2002 & 1996-1998 & 1999-2002 & 1996-2002 & 1996-1998 & $1999-2002$ & 1996-2002 & 1996-1998 & $1999-2002$ \\
\hline & Intotrev & Intotrev & Intotrev & Intotrev & Intotrev & Intotrev & Intotrev & lntotrev & Intotrev \\
\hline \multirow[t]{2}{*}{ Lnpf } & $-0.04512 * *$ & $-0.12283 * * *$ & $0.11303 * * *$ & -0.02784 & -0.00310 & 0.03510 & $-0.03216^{* *}$ & $-0.03733 * *$ & $0.07107 *$ \\
\hline & {$[0.01916]$} & {$[0.02644]$} & {$[0.03134]$} & {$[0.03353]$} & {$[0.04704]$} & {$[0.05400]$} & {$[0.01619]$} & {$[0.01735]$} & {$[0.03787]$} \\
\hline \multirow[t]{2}{*}{ Lnpl } & 0.00039 & -0.00157 & 0.00185 & 0.00976 & -0.00533 & 0.01196 & -0.01595 & 0.02333 & $-0.02762 *$ \\
\hline & {$[0.00375]$} & {$[0.00640]$} & {$[0.00544]$} & {$[0.01102]$} & {$[0.01920]$} & {$[0.01332]$} & {$[0.01558]$} & {$[0.03607]$} & {$[0.01666]$} \\
\hline \multirow[t]{2}{*}{ Lnpk } & $0.00273^{* * *}$ & -0.00019 & $0.00314^{*}$ & 0.00024 & $-0.00455^{* * *}$ & 0.00227 & -0.00097 & 0.00074 & -0.00204 \\
\hline & [0.00099] & {$[0.00135]$} & {$[0.00186]$} & {$[0.00150]$} & {$[0.00214]$} & {$[0.00289]$} & {$[0.00147]$} & {$[0.00206]$} & {$[0.00190]$} \\
\hline \multirow[t]{2}{*}{ Lnloass } & $0.00306 * *$ & $0.00550 * * *$ & $0.01340^{* * *}$ & $0.00742 * * *$ & $0.01015^{* * * *}$ & $0.01690 * * *$ & $0.00193 * *$ & $0.00279 *$ & $0.01065^{* * *}$ \\
\hline & {$[0.00127]$} & {$[0.00207]$} & {$[0.00268]$} & {$[0.00192]$} & [0.00307] & {$[0.00431]$} & [0.00089] & {$[0.00166]$} & [0.00257] \\
\hline \multirow[t]{2}{*}{ Lneqty } & $0.11326^{* * *}$ & $0.08950 * * *$ & $0.10343 * * *$ & $0.21905^{* * *}$ & $0.25776^{* * *}$ & $0.10769 * *$ & 0.01059 & 0.01333 & $0.04160 * * *$ \\
\hline & {$[0.00960]$} & [0.01196] & {$[0.03217]$} & {$[0.02284]$} & {$[0.03348]$} & {$[0.05011]$} & {$[0.00875]$} & {$[0.01646]$} & [0.01436] \\
\hline \multirow[t]{2}{*}{ Lnintbankdep } & 0.00017 & 0.00178 & -0.00089 & 0.00082 & 0.00025 & 0.00107 & $-0.00071 * * *$ & $-0.00169 * * *$ & $-0.00083^{*}$ \\
\hline & {$[0.00078]$} & {$[0.00148]$} & [0.00123] & {$[0.00123]$} & {$[0.00219]$} & [0.00187] & [0.00027] & {$[0.00048]$} & {$[0.00043]$} \\
\hline \multirow[t]{2}{*}{ Lntassets } & $-0.0094 * * *$ & $-0.00874 * * *$ & -0.00577 & -0.00414 & 0.00259 & -0.00730 & $-0.00665 * * *$ & $-0.00367 * *$ & $-0.00385^{* *}$ \\
\hline & {$[0.00163]$} & {$[0.00268]$} & {$[0.00379]$} & {$[0.00275]$} & [0.00427] & {$[0.00635]$} & {$[0.00086]$} & {$[0.00157]$} & {$[0.00172]$} \\
\hline \multirow[t]{2}{*}{ Constant } & $0.09056^{* * *}$ & $0.08037 * * *$ & 0.03327 & 0.02563 & -0.03571 & 0.02468 & $0.07740 * * *$ & $0.05458 * * *$ & 0.02537 \\
\hline & [0.01199] & {$[0.01752]$} & {$[0.03744]$} & [0.02069] & [0.02990] & {$[0.06004]$} & {$[0.00821]$} & {$[0.01455]$} & {$[0.02012]$} \\
\hline$\overline{\mathrm{Obs}}$ & 2468 & 1406 & 1062 & 1223 & 717 & 506 & 832 & 459 & 373 \\
\hline R-squared & 0.14 & 0.11 & 0.12 & 0.16 & 0.14 & 0.11 & 0.51 & 0.45 & 0.30 \\
\hline Hausman test & 145.94 & 84.35 & 117.75 & 150.64 & 117.07 & 79.71 & 140.16 & 47.60 & 186.23 \\
\hline ( $p$ value) & $(0.000)$ & $(0.000)$ & $(0.000)$ & $(0.000)$ & $(0.000)$ & $(0.000)$ & $(0.000)$ & $(0.000)$ & $(0.000)$ \\
\hline$\overline{\mathrm{H}}$ stat & -0.042 & -0.124 & 0.1180 & -0.01784 & -0.0129 & 0.04976 & -0.04908 & -0.0132 & 0.04141 \\
\hline Ho & $4.53 b$ & $20.50 \mathrm{a}$ & $749.00 \mathrm{a}$ & 0.25 & 0.06 & 0.76 & $5.01 \mathrm{~b}$ & 0.12 & 1.06 \\
\hline $\mathrm{H} 1$ & $2790.84 a$ & 1670.10 & $13.41 \mathrm{a}$ & $813.93 a$ & $385.25 \mathrm{a}$ & $283.82 \mathrm{a}$ & $2288.47 \mathrm{a}$ & $683.77 \mathrm{a}$ & $568.22 \mathrm{a}$ \\
\hline
\end{tabular}

Standard errors in brackets. $*$ significant at $10 \% ; * *$ significant at $5 \% ; * * *$ significant at $1 \%$.

$\mathrm{H} 1: F$ statistic for testing the hypothesis $\mathrm{H}=1 ; \mathrm{H} 0: F$ statistic for testing the hypothesis $\mathrm{H}=0$. c: significant at $10 \%$; b: significant at $5 \%$ and a: significant at $1 \%$ 
for the whole sample (panel A). Therefore the French financial market is characterised by monopolistic competition. These results extend the evidence of Molyneux (1994) and Davis (2000) for the new periods of study. The value of the $\mathrm{H}$ statistic in the last part of the sample 1999-2002 is greater than in the first subperiod 1996-98. Therefore, the introduction of the EMU seems to have a beneficial effect on competitive conditions, at least in the banking sector as a whole. Furthermore, the value of the $\mathrm{H}$ statistic is lower than that estimated for the UK and Denmark, meaning that the competitive conditions of the French banking system are not as demanding as in the two non-EMU countries.

The analysis of commercial banks and non-profit institutions ${ }^{18}$ separately seeds some light on the different behaviour of the market for each kind of institution. For French commercial banks, the existence of a monopoly situation can not be rejected when we consider the whole period, whereas non profit organizations place themselves in a monopolistic competition environment. The analysis for the sub-periods reveals that for both, commercial banks and mutual and savings banks, the existence of a monopoly situation can not be rejected. However, the post EMU H-statistic increases. This increase is even greater for the non profit institutions that reduce the distance with commercial banks. Therefore, EMU has had a positive effect on competition for the two kinds of institutions of the French market.

Comparing all countries, the banking system of non EMU countries, Denmark and UK, is more competitive than EMU countries, Spain and France. Besides the competitiveness worsens, reducing the distance among them when the whole banking system is considered. Distinguishing between financial institutions, Spanish and French commercial banks develop their activity in a more competitive market along the period whereas the Danish and UK banks show the opposite result. Furthermore, Spanish commercial banks present higher H statistic meaning that the competitive conditions of the Spanish commercial banks are more demanding than in the UK Therefore, the differences between EMU and non EMU commercial banks reduce in the last part of the sample.

On the other side, UK non-profit institutions enjoyed greater competitive conditions than Spanish and French ones at first but the situation changes in the post-Euro period for the case of UK and Spain. Although both operate in a

\footnotetext{
${ }^{18}$ In the case of France there are two financial institutions that bear this characteristic: mutual banks and savings banks. They are considered together in the analysis. The individual analysis of each type of institutions offers similar results.
} 
monopolistic competition situation, Spanish savings banks face a more competitive environment than UK building societies. Hence, it seems that non for profit institutions retain a greater level of market power in product and geographic areas. ${ }^{19}$ French non profit institutions also improve their competitive conditions. Therefore, the consideration of ownership structure reveals some differences that do not arise when analysing the industry as a whole. Besides the additional evidence, the distinction of ownership structure is also important to the assumptions of the methodology applied. The Panzar and Rose statistic assumes homogeneous cost structure in the industry. The differences in the objective functions of profit and non-for profit institutions and the strategy accordingly developed, make it difficult to consider the cost structure homogeneous.

\section{Conclusions}

The adoption of the European single currency was assumed to be an extra impulse to competition, approaching perhaps the level of a liberalised and continental market like the United States. However, exact convergence with the US was unlikely due to barriers to EU integration such as different domestic regulations and tax systems. This paper analyses the evolution and consequences of this economic and financial integration in the degree of competition in the banking industry. The analysis is carried out for UK, Denmark, France and Spain, during the period 1996-2002, taking into account the important differences in ownership structure of the main institutions competing in these markets. That is, the comparison is made between typical commercial banks and non-for-profitorganizations such as Building Societies in the case of UK, Spanish, Danish and French Savings banks. All markets share important deregulation processes in the period studied.

The results highlight first, that the competitive environment evolves differently outside and inside the single monetary union. EMU adoption helps to increase competition both for Spanish and French banking systems (both for commercial and savings banks) whereas, in the same period, the UK and Danish systems show a decrease or remain nearly unchanged. Hence, there is evidence of the positive effect of the Single currency on the degree of competition in the banking industry.

\footnotetext{
${ }^{19}$ In the case of France there are two financial institutions that bear this characteristic: mutual banks and savings banks. They are considered together in the analysis. The individual analysis of each type of institutions offers similar results.
} 
This positive impact could suggest that the introduction of the Single currency would help to improve competition in the banking markets of new single currency adopters.

Second, the distinction between different ownership structures matters when it comes to competition analysis. Non profit financial institutions enjoy a low competitive situation with a dominant position in regional and local markets, whereas commercial banks, in all countries, experience a more competitive scenario. This difference may help to explain the viability and success of the former in the past. Another difference has to do with the evolution. UK Building societies and Danish savings banks view a slight reduction in the competitive pressures, while Spanish and French non-for profit organizations face an important increase in competition during the years of study. Therefore, the deregulation process and the adoption of the EMU have altered mainly the idyllic situation of savings banks, especially in the Spanish case. These results are closely related to the on-going debate on the legal status and corporate ownership structure of non profit financial institutions and may help in this discussion, turning attention to the relevance of monetary integration in banking sectors.

\section{Acknowledgements}

We are grateful to Paolo Coccorese for his helpful comments and suggestions. We have benefited from the comments of participants to the European Meeting of FMA 2004. This paper started while Natalia Utrero-González was visiting CSEF, Università di Salerno. Natalia Utrero-Gonzalez acknowledges financial support from the European Commission RTN Understanding Financial Architecture: Legal and Political Frameworks and Economic Efficiency [Contract Number: HPRN-CT-2000-00064] and financial support from the Spanish Ministry of education (SEJ 2004-07530-C04/ECON). Francisco J. Callado Muñoz acknowledges financial support from the Spanish Ministry of education (SEJ200403276/ECON). All errors are our own responsibility.

Received 16 May 2006, Accepted 9 October 2006

\section{References}

Angelini, P., Cetorelli, N. (2000), Bank Competition and Regulatory Reform : The Case 
of The Italian Banking Industry, Banca D'italia, Servizio Di Studi, Paper 380. Arellano, M, Bover, O. (1990), La Econometria De Datos De Panel. Investigaciones Económicas, 14(1): 3-45.

Ashton, J. K. (2000). A General Test of Competitive Conditions in UK Building Societies: 1990-95, The Service Industries Journal, 20 (1), 87-95.

Bresnahan, T. F. (1982), The Oligopoly Solution Concept Is Identified, Economic Letters, 10: $87-92$.

Bikker, J.A., Groeneveld, O. (2000), Competition and Concentration in The EU Banking Industry, Kredit Und Capital, 33: 62-98.

Bikker, J. A., Haaf, K. (2002), Competition, Concentration And Their Relationship: An Empirical Analysis Of The Banking Industry, Journal of Banking and Finance, 26: 2191-2214.

Building Societies Annual Report, (2000), Building Societies Association.

CECA (2004), Informe annual, Confederación Española de Cajas de Ahorro.

Chiappori, P.A., Perez-Castrillo, D., Verdier, T. (1995), Spatial Competition in The Banking System: Localisation, Cross Subsidies and The Regulation of Deposit Rates, European Economic Review, 39: 889-918.

Claessens, S., Laeven, L. (2004), What Drives Bank Competition? Some International Evidence, Journal of Money, Credit and Banking, 36: 585-592.

Coccorese, P. (1998a), Assessing The Competitive Conditions In The Italian Banking System: Some Empirical Evidence, BNL Quarterly Review, 205: 171-191.

Coccorese, P. (1998b), The Degree of Competition In The Italian Banking Industry, Economic Notes 3: 355-370.

Coccorese, P. (2004), Banking Competition And Macroeconomic Conditions: A Disaggregate Analysis Journal of International Financial Markets, Institutions And Money, 14(3): 203-218.

Cook, J, Deakin, S., Hughes, A. (2001), Mutuality and Corporate Governance: The Evolution of UK Building Societies Following Deregulation" ESCR WP 205.

Crespi, R., Garcia-Cestona M.A., Salas, V. (2003), Governance Mechanism In Spanish Banks. Does Ownership Matters?, ECGI Finance WP 19.

Cruickshank, D. (2000), Executive Summary, Competition in the UK Banking, A Report to the Chancellor, Crown.

De Bandt O., Davis, E. P. (2000), A Cross Country Comparison of Market Structures in European Banking", Journal of Banking and Finance, 26: 1045-1066.

Drake, L., Simper. R. (2003), Competition and Efficiency in UK Banking: The Impact of Corporate Ownership Structure. Mimeo.

Dermine, J. (2002), European Banking, past, present and future. INSEAD.

European Central Bank (1999), Possible effects of EMU on the EU Banking Systems in the medium to long term.

Hansmann, H. (1996), The Ownership of Enterprise, Harvard University Press, Cambridge, Ma.

Hondroyiannis, G., Sarantis, L., Papapetrou, E. (1999), Assessing Competitive Conditions 
in the Greek Banking System, Journal of International Financial Markets, Institutions And Money, 9: 377-391.

Koutsomanoli-Filipaki, N., Staikouras, C. (2004), Competition and Concentration in the New European Banking Landscape, Department Of Accounting And Finance, Athens University, Mimeo

Lau, L. (1982), On Identifying the Degree of Competitiveness From Industry Price and Output Data", Economic Letters, 10: 93-99.

Maudos, J., Perez, F. (2003), Competencia versus Poder de Mercado en la Banca Española”, Moneda y Crédito, 217: 139-167.

Molyneux, P., Lloyd-Williams, D. M., Thornton, J. (1994), Competitive Conditions In European Banking, Journal of Banking and Finance, 18: 445-459.

Molyneux, P., Lloyd-Williams, D. M., Thornton, J. (1996), Competition and Market Contestability in the Japanese Commercial Banking Market, Journal of Economic and Business, 48: 33-45.

Nathan, A., Neave, E. H. (1989), Competition and Contestability iln Canada's Financial System: Empirical Results, Canadian Journal Of Economics, 22: 576-594.

Panzar J. C., Rosse, J. N. (1982), Structure, Conduct and Comparative Statistic, Bell Laboratories Economic Discussion Papers, N. 248

Panzar J. C., Rosse, J. N. (1987), Testing For Monopoly Equilibrium, The Journal of Industrial Economics, 35: 443-456.

Rosse J. N., Panzar, J.C. (1977), Chamberlin vs. Robinson: An Empirical Test for Monopoly Rents, Bell Laboratories Economic Discussion Papers, N. 90

Shaffer, S. (1982), Competition Conduct And Demand Elasticity, Economic Letters, 10: 167-171.

Shaffer, S. (1989), Competition in the US Banking Industry, Economic Letters, 29: 321323.

Shaffer, S. (1993), A Test of Competition in Canadian Banking, Journal of Money, Credit and Banking, 25: 49-61.

Staikouras, C., Wood, G., (2000), Competition and Banking Stability in The Euro Area: the Cases for Greece And Spain, The Journal of International Banking Regulation, 2(1): 7-24.

Tirole, J. (1988), The Theory Of Industrial Organizations, Mit Press

Vesala, J. (1995), Testing Competition In Banking: Behavioural Evidence From Finland, Bank Of Finland Studies, E1.

Yildirim, H. S., Philippatos. G. C. (2006), Competition and Contestability in Central and Eastern European Banking Markets", Managerial Finance, Forthcoming.

White, H. (1980), A Heteroskedasticity-Consistent Covariance Matrix Estimator And A Direct Test For Heteroskedasticity, Econometrica, 48: 817-838. 